Hui Li* and Jiasheng Zhang

\title{
How do Civic Associations Foster Political Participation? The Role of Scope and Intensity of Organizational Involvement
}

DOI $10.1515 / \mathrm{npf}-2016-0010$

\begin{abstract}
This paper investigates factors associated with individuals' decisions in engaging in various modes of political participation, including voting, formal and informal political activities. Two aspects of civic association involvement are highlighted: scope and intensity. Using data from the U.S. Citizenship, Involvement, and Democracy Survey in 2006, we find that one's memberships in civic associations only explain one's participation in formal political activities, but the intensity of involvement, measured by the number of activities one performs at one's most active voluntary association, is positively associated with both formal and informal participation modes. Neither the scope nor the intensity explains voting behavior. The study suggests ways to promote the development of civic associations and enhance democracy.
\end{abstract}

Keywords: political participation, civic associations

\section{Introduction}

Political participation is vital to democracy (Tocqueville 2002; Fung 2003; Verba and Nie 1972; Verba, Schlozman, Brady 1995). Why people participate in political life has thus been an important research question for generations of scholars. Starting with the seminal works of Downs (1957) and Olson (1965), many scholars have examined the causes of political participation. Downs (1957) adopts an economic perspective, arguing that it is irrational to vote if the probability that a single vote will make a difference to the outcome of the election is minuscule. Building upon Downs' argument, Olson (1965) proposes that rational individuals

\footnotetext{
*Corresponding author: Hui Li, School of Public Administration, University of Central Florida, Orlando, FL, USA, E-mail: Hui.Li@ucf.edu

Jiasheng Zhang, Askew School of Public Administration and Policy, Florida State University, Tallahassee, FL 32306, USA, E-mail: jz13j@my.fsu.edu
} 
will not contribute time, money, or effort to public goods unless selective incentives are provided. These ideas help establish a general framework for the rational choice theory.

Following the rational choice theory, scholars have tried to empirically examine the effects of various factors on political participation. They first focus on the personal-level indicators, such as income, education, psychological involvement, political efficacy, or party identification. The standard socioeconomic model, or the resource model, developed by Verba and colleagues (e. g., Brady, Schlozman, and Verba 1999; Brady, Verba, and Schlozman 1995; Verba et al. 1993; Verba, Schlozman, and Brady 1995), is the most influential one. It proposes that participation is primarily driven by individuals' resources (i. e., time, money). High-status individuals are more likely to participate in politics than low-status individuals (Milbrath 1965; Verba, Schlozman, and Brady 1995). A second group of scholars focuses on the mobilization effect. It asserts that participation is a response to contextual cues structured by the individual's environment. Individuals participate in politics because they are asked (through either institutional or informal channels) to do so (Kitts 2000; Lim 2008). These two mechanisms are succinctly summarized in Brady, Verba, and Schlozman (1995), in which they state that "they can't, they don't want to," or "nobody asked" can best explain the puzzle for political participation.

Another stream of research emphasizes the importance of "organizational life." Scholars assert that civic associations are the training ground where citizens learn meaningful democratic skills and foster civic virtues and collective efficacy (Andrews et al. 2010; Berry, Portney, and Thomson 1993; Tocqueville 2002; Putnam 2000; Schachter 2011; Verba, Schlozman, and Brady 1995). A number of scholars have empirically tested the effects of civic associations on political participation. Some focus on association memberships, arguing that the more one is affiliated with civic associations, the more one is involved in political activities (Lim 2008; Quintelier 2008; Wollebæk and Strømsnes 2007). Other scholars "get into the organization" and focus on the activities one performs in civic associations. They propose that the extent to which one is active in associational activities is more important than memberships in political participation (Alexander et al. 2010; Sobieraj and White 2004). Somma (2010), for example, finds that protest participation is positively associated with one's commitment of time and money to civic organizations. Therefore, both membership and degree of involvement seem important, but which one matters more is inconclusive.

To summarize, one's organizational life, along with one's socioeconomic characteristics and network mobilization, are critical to political participation. They have been studied by scholars from different disciplines. In addition, most research treats political action as a single-dimension variable measured by 
voting behavior or the number of political activities in which individuals engage. However, political participation is not simply equated with voter turnout, nor is it the simple aggregation of different activities. Rather, it is a multidimensional concept that includes different forms of political action, such as formal or informal participation (Newman and Bartels 2010).

This study contributes to the literature by distinguishing various modes of political participation and by specifying the mechanisms under which civic associations influence political participation. Specifically, we categorize political participation into three modes: voting, formal, and informal participation. We propose that these modes vary in their degree of institutionalization, the number of people involved, the difficulty of acts, and the degree of policy influence. In addition, we identify two aspects of associational life - the scope and the intensity - and find that they relate to the various modes of political participation differently. The study proceeds this way. First, we review various streams of literature and explain how civic associations are related to different modes of political participation. Second, we use the data from the U.S. Citizenship, Involvement, and Democracy Survey in 2006 to test a set of hypotheses. Following that, findings are presented. We conclude the paper by summarizing the main findings and the implications of the research.

\section{Theory and Hypotheses}

Political participation is defined as "those actions of private citizens by which they seek to influence or to support government and politics” (Milbrath 1981, 198). Civic associations are organized and governed by private individuals in their capacities as citizens who are concerned with public matters (Andrews et al. 2010; Salamon and Anheier 1992). They depend on members' voluntary efforts for management and operation. They often have a decentralized decision making process during which members' collective voices can be heard. The relationship between civic associations and political participation has long been studied. In this paper, we first distinguish three types of political participation: voting, formal, and informal participation. How civic associations are related to them is then presented.

\subsection{Three Modes of Political Participation}

Political participation not only includes voting but also encompasses various forms of other political activities, such as volunteering for a political candidate 
Table 1: The differences among various modes of political participation.

\begin{tabular}{lllll}
\hline Participation forms & $\begin{array}{l}\text { Degree of } \\
\text { institutionalization }\end{array}$ & $\begin{array}{l}\text { Individualized vs. } \\
\text { group-based }\end{array}$ & $\begin{array}{l}\text { Difficulty } \\
\text { of actions }\end{array}$ & $\begin{array}{l}\text { Policy } \\
\text { influence }\end{array}$ \\
\hline Voting & High & Individualized & Low & Low \\
Formal participation & Moderate & Mixed & High & Medium \\
Informal participation & Low & Mixed & High & High \\
\hline
\end{tabular}

or campaign, contacting government officials, attending meetings of local government boards or councils, signing petitions, or engaging in protests or demonstrations. These activities can be categorized into three types: voting, formal, and informal participation. They differ in a variety of ways (See Table 1; Newman and Bartels 2010; Verba, Schlozman, and Brady 1995). First, they vary in the degree of institutionalization. Some political acts, such as voting, are highly institutionalized; they operate within the well-established formal or legal channels. In contrast, some political activities, such as informal, are loosely structured outside the formal institutional channels (McAdam 2010). Second, some participation forms are individualized, whereas others are group-based (Klandermans 2003; Pattie, Seyd, and Whiteley 2003). For example, voting is a highly individualized political act, whereas formal and informal forms of participation may be shaped by group interactions and social networks. Third, the three forms of participation vary in terms of the "difficulty of the act" (Verba and Nie 1972), with some requiring less time and effort to carry out and others more. For example, voting requires less initiative, whereas formal or informal forms of political acts, such as protesting or contacting officials, require more time, money, and skills (Verba, Schlozman, and Brady 1995). In addition, the three modes provide varying degree of information about citizens' preferences, interests, and needs, and they differ in their influence on public policy (Verba, Schlozman, and Brady 1995; Walker 2008). Voting, for example, often conveys ambiguous information about voters' preferences and provides an infrequent and blunt instrument for political influence (Dalton 2008; Verba et al. 1993). In other words, voting only occurs every several years, and waiting that long to vote down the administration that one is dissatisfied with seems like political inaction. Instead, some political acts, such as contacting government officials or signing a petition, seem to be more direct means of expressing political concerns and influencing policy makers (Dalton 2008; Norris 2002; Stolle, Hooghe, and Micheletti 2005; Wuthnow 2002; Zukin et al. 2006).

Given the distinctions in the modes of political participation, it is likely that factors associated with them vary. While existing research on political participation has mostly focused on individuals' socioeconomic status and network 
relations, this study highlights the role of "organizational life" in political participation. Below, we examine how civic associations influence political participation. Specifically, we distinguish two aspects of civic participation, scope and intensity, and relate them to different modes of political participation.

\subsection{Civic Associations and Political Participation}

Civic associations have long been considered critical to political participation. More than a century ago, Tocqueville (2002) argued that civic associations do not only empower individuals but also serve as a learning school for democracy. Almond and Verba (1963) stressed on the importance of civic associations in fostering a democratic political culture and in providing their members with an increased sense of political efficacy. Civic associations may also function as agents of mobilization through disseminating political information and encouraging group discussions (Eliasoph 1998; Pollock 1982).

In examining the role of civic associations, most studies use the "membership approach," which uses either binary variables to indicate whether one belongs to certain associations, or a simple count of the number of organizational memberships one has (Somma 2010). While this measure focuses on the scope of organizational involvement, it neglects the intensity of the involvement, which is essential in fostering political participation (Wollebæk and Strømsnes 2007). Below we consider both aspects of organizational involvement and propose competing hypotheses.

\subsubsection{The Scope of Organizational Involvement}

Scholars argue that the scope of organizational involvement, which is measured by the number of affiliations to which one belongs, is important in fostering political participation (Hooghe 2003; Leighley 1996; Lim 2008; Mutz 2002; Paik and Navarre-Jackson 2010; Paxton 2002 2007). They believe that multiple affiliations in civic associations provide non-redundant information, cultivate shared identification and trust, and convey a sense of cooperation and efficacy.

First, overlapping memberships indicate crosscutting ties, which function as information systems, i. e., the bridging form of social capital that Burt (2000) advocates. These bridging ties help disseminate knowledge about current issues and how the association relates to them. A majority of civic associations now send their members published newsletters, through which participants can be informed about the goings-on in the association. Second, overlapping 
memberships in several associations can cultivate a sense of identification and trust, which can be transferred to several contexts and possibly to society as a whole (Lim 2008; Park and Subramanian 2012; Wollebaek and Selle 2002). Third, membership conveys a sense of the value of cooperation for common purposes and of political efficacy (Paxton 2007). Therefore, it is likely that individuals with more affiliations will participate more in politics. For example, in a case study on an American civic association, Erickson and Nosanchuk (1990) showed that associational involvement positively influences political involvement by bringing participants into contact with politically active friends. Wollebæk and Strømsnes (2007) found that multiple memberships have a very strong effect on political engagement, because overlapping membership between different organizations helps develop and disseminate social trust. Similarly, Alexander et al. (2010)'s study revealed that people who associate with a wider range of groups are more likely to be politically engaged than those who are active within a small number of groups.

The effect of the scope of civic association on political participation may vary across modes. Given that voting is a relatively individualized and anonymous political act, it may not be affected by memberships. In contrast, formal and informal modes of participation may be mobilized by overlapping networks. Therefore, we hypothesize as follows,

$\mathrm{H} 1 \mathrm{The}$ number of affiliations in civic associations is positively associated with formal mode of political participation.

$\mathrm{H} 2$ The number of affiliations in civic associations is positively associated with informal mode of political participation.

\subsubsection{The Intensity of Organizational Involvement}

Contrary to the membership approach, scholars like Putnam (2000) and Skocpol, Ganz, and Munson (2000) emphasized the benefits (e.g., social capital, trust, norms) accrued from intense interactions within civic associations. Putnam (2000) believed that frequent face-to-face contact between members helps foster societal trust and cooperative behavior which are essential to the vitality of American democracy. He claimed that social capital in the United States is declining, because active voluntary associations are being replaced by growing tertiary organizations (i. e., mailing list) in which members do not interact personally. Skocpol, Ganz, and Munson (2000) took it one step further and proposed that multi-tiered national federations consisting of robust local chapters are key supports of classic American voluntarism because they offer an institutional framework in which nationwide leadership 
networks are sustained and career lines, resources, and incentives for membership organizers are provided.

Individuals participate in civic associations by engaging in or even shaping organizational activities, which include going to meetings where they take part in decision making, planning or chairing a meeting, giving public speeches, among others. Through participating in these activities, one may foster confidence and efficacy, acquire democratic skills, inculcate civic virtues, and gain political knowledge. Hence, those individuals who are more involved, or who participate in more organizational activities, are considered "active members," and they are likely to engage more in politics because of their public-spiritedness and skills (Quintelier 2012; Somma 2010; Wollebæk and Strømsnes 2007; Wollebaek and Selle 2002). As Berry, Portney, and Thomson (1993) eloquently put, civic association "teaches people about the operations of governments, affords them the opportunity to understand the potentials and limits of their own personal influence, sharpens their cognitive skills and gives them the experience necessary to develop self-confidence in their abilities” (p. 256).

Nonetheless, this effect may vary across different modes of political participation. As voting is a highly individualized and low-initiative political act, it may not be affected much by the extent to which one engages in civic associations. The other two modes of political acts, including formal and informal participation, may be fostered by one's intensity of involvement in civic associations. For example, through engaging in group discussions, one may have more ideas of what constitutes effective political action and may act on it (Eliasoph 1998; Pollock 1982). Thus, the hypotheses are as follows,

H3 The depth of involvement in civic associations is positively associated with

formal mode of political participation.

H4 The depth of involvement in civic associations is positively associated with informal mode of political participation.

\section{Data and Method}

\subsection{Data Sources}

To examine factors associated with different types of political participation, this study uses data from the U.S. "Citizenship, Involvement, and Democracy" (CID) Survey, which was conducted by the Center for Democracy and Civil Society at Georgetown University in 2006 (Howard, Gibson, and Stolle 2006). The survey consisted of in-person interviews with a representative sample of 1,001 
Americans whose age were 18 years old or over. The survey employed a clustered sample design and achieved an overall response rate of $40 \%$. The CID Survey covered a variety of questions, related to the participants' socioeconomic status, political participation, voluntary associations, and personal networks. Compared to the American Citizen Participation Study (Verba et al. 1990), ${ }^{1}$ which is a widely-used dataset over the past two decades, the CID data provides comparable level of details, but with updated information.

\subsection{Dependent Variables}

Three different modes of political participation are measured. The first is binary, measuring one's participation in voting. The second set of dependent variables measures different forms of political participation. It is derived from a question that asked whether a respondent had participated in any of the 11 political activities in the year prior to 2006. Examples include contacting a politician or a local government official, signing a petition, donating money to a political organization or group, and participating in illegal protests. Based on the characteristics of these activities, we categorize them into two distinct modes of political participation - formal and informal. Formal participation captures those activities that are more formal and institutionalized. The variable consists of six items, including 1) contacting a politician or a local government official; 2) working in a political party or action group; 3) working for the campaign of a candidate for office; 4) working in another political organization or association; 5) wearing or displaying a campaign badge/ sticker; and 6) donating money to a political organization or group. A higher scale variable is created by summing the six items. Informal participation involves those activities that are more informal and non-institutionalized. This variable consists of five items, including 1) signing a petition; 2) taking part in a lawful public demonstration; 3) boycotting a certain product; 4) deliberately buying certain products for political or ethical reasons; and 5) participating in illegal protests. The variable is calculated by summing the above five items.

\footnotetext{
1 The American Citizen Participation Study (ACPS) is a survey of adults living in the United States in 1989 and 1990. It was designed to examine political and nonpolitical civic participation. In the survey, respondents were asked to provide information on various topics, including their interest in politics and their party identification, voting status, and activity in community politics. Information on campaign activities and personal experiences with government programs and opinions on national and social problems was also collected.
} 


\subsection{Independent Variables}

Two aspects of organizational involvement in civic associations are measured: the scope and the intensity. The scope of organizational involvement is measured by the number of affiliations that one participates in any of the fifteen civic associations, including 1) sports clubs, 2) cultural or hobby groups, 3) trade unions, 4) business or professional organizations, 5) consumer or automobile organizations, 6) human rights organizations, 7) religious organizations, 8) political parties, 9) neighborhood/homeowner associations, 10) veteran's organizations, 11) ethnic or racial groups, 12) self-help groups, 13) organizations for environmental protection, peace, or animal rights, 14) organizations for science, education, or teachers and parents, and 15) organizations that provide social services to the needy. The intensity of organizational involvement is a scale ranging from 1 to 4 where 1 means one participates in one of the following activities, including writing a letter, going to a meeting where one took part in making decisions, planning or chairing a meeting, or giving a presentation or speech in the organizations that one is most active at, and 4 means one participates in all 4 activities.

\subsection{Control Variables}

The first set of control variables concerns one's socioeconomic status. According to the standard socioeconomic model, which was first elucidated by Verba and Nie (1972), political participation is primarily driven by one's socioeconomic status and civic orientations. As high-status individuals are better located in the social environments, they have more resources and opportunities to enhance and cultivate participatory norms and civic skills. Thus, compared to low-status individuals, those in a high socioeconomic status are more likely to participate in politics.

Income and education are among the most important variables to measure one's socioeconomic status. Education, because it enhances political interest and civic skills, and income because of the monetary resources that it provides. Verba, Schlozman, and Brady (1995) and Kam and Palmer (2008), for example, argue that education allows citizens to acquire necessary civic skills to understand abstract political issues and communicate their concerns to government officials and politicians. Therefore, people with higher income and education may be more likely to use institutionalized channels, such as voting and formal forms, to participate in politics. Given these options, they may not choose to use informal means of participation. 
Income is a categorical variable measuring a household's total annual net income. $^{2}$ It consists of eleven categories, with the lowest being less than $\$ 15,000$, and the highest \$200,000 or more. Similarly, education is a categorical variable. It covers 6 levels of educational attainment: 1) None, or grades 1-8, 2) High school incomplete - grades 9-11, 3) Business, technical, or vocational school after high school, 4) Some college, no 4-year degree, 5) College graduate, and 6) Post-graduate training, professional schooling after college. It is expected that individuals with higher income and education are more likely to engage in voting and formal mode of political participation.

The second set of control variables examines one's network mobilization. The mobilization approach asserts that individuals are embedded in their social networks where contextual cues and political opportunities may be supplied and participation may be mobilized. Being asked to participate by one's political party, groups of affiliation, family, friends, or others in the social networks, makes one more likely to engage in political activities (e. g., Booth and Richard 1998; Brady, Schlozman, and Verba 1999; Bratton 1999; Huckfeldt and Sprague 1992; Kenny 1992; Knoke 1990). In the social movement literature, for example, many studies have highlighted the positive association between recruitment and the likelihood of one's engagement in protests, boycotts, or the like (Diani and McAdam 2003; Fernandez and McAdam 1988; McAdam and Paulsen 1993; Walker 2008). Therefore, mobilization allows people to live beyond personal resource constraints and may narrow the participation gap between low and high-status individuals (McClurg 2003).

Mobilization is a binary variable that captures whether an individual was asked to vote, to contribute money to a political cause, or to engage in some other type of political activity. It is coded as 1 if the individual was asked, 0 otherwise.

In addition, several other control variables, including age, gender, race, party identification, political interests, and political efficacy, were considered. Age is a subtraction of the year or birth from 2005, the year of the survey. It ranges from 18 to 90 . Gender is a binary variable in which 1 refers to male and 0 otherwise. The variable on race encompasses four dummy variables where whites serve as the reference group. Party identification consists of two

2 According to the data coding handbook, the original question on the main income variable has a great deal of missing data (including 95 refused, 29 don't know, 10 no answer). To correct missing data problem, in the appendix of the released dataset, the author of the dataset, Howard, Gibson and Stolle constructed a new variable - adjusted income - which is based on imputations from a combination of homeownership, the interviewer's estimate of the respondent's social class, the respondent's response to a question about "how you feel about your household's income nowadays", and a follow-up question about whether the respondent's income is "under $\$ 50,000$ or $\$ 50,000$ or more". 
dummy variables where the independent serves as the reference group. The variable on political interests measures how interested one is in politics, where 1 refers to she/he is not at all interested, 2 not very interested, 3 somewhat interested, and 4 very interested. The last control variable, political efficacy, is constructed from the question - "do you think that politicians care what people like you think?" This is a 5-point scale variable, in which 1 refers to "hardly any politics care what people like me think," and 5 means "most politicians care what people like me think."

\subsection{Analytic Techniques}

As voting is a binary dependent variable, a logistic model is used. Given that both formal and informal participation are count dependent variables and their standard deviations are larger than their means, negative binomial regression models are used (Cameron and Trivedi 2013; Long and Freese 2006). All the data analysis is conducted using Stata 12.

\section{Results}

Table 2 shows the descriptive statistics for the variables. On average, American citizens participated in 2 out of 14 political activities in 2006. This echoes Putnam (2000)'s argument regarding the decline of civic engagement. ${ }^{3}$ Compared to informal participation, citizens engage more in formal political activities. Cross-tabulation results reveal that individual Americans who engage in voting are also significantly more likely to participate in formal political activities (chi-square $=81.07, p<0.000$ ). The results are similar in any other two pairs of cross-tabulations. Thus, we suspect that the strong relationship across different types of political participation is in large part due to the shared individual- or organizational-level attributes (Jeong 2013).

3 In Bowling Alone, Putnam presented a series of evidence regarding the decline of civic engagement: 1) voter turnout had declined by nearly a quarter from a relative high point in the early 1960s to 1990; 2) membership in traditional women's groups had steadily declined; 3) the number of volunteers for civic organizations had significantly reduced; 4) the number of Americans who report that "in the past year they have attended a public meeting on town or school affairs" had fallen from $22 \%$ in 1973 to $13 \%$ in 1993; 5) the proportion of Americans who reply that they "trust the government in Washington" only "some of the time" or "almost never" had risen steadily from 30\% in 1966 to $75 \%$ in 1992 (Putnam 2000, 65-78). 
Table 2: Descriptive statistics.

\begin{tabular}{lrr}
\hline Variables & Mean & $\begin{array}{r}\text { Std. } \\
\text { Deviation }\end{array}$ \\
\hline Formal mode of participation (count) & 0.84 & 1.38 \\
Informal mode of participation (count) & 0.81 & 1.14 \\
Voting (binary) & 5.29 & 2.44 \\
Membership in civic associations (count) & 1.25 & 1.36 \\
Depth of involvement in the most active & 44.91 & 16.86 \\
$\quad$ organizations (scale) & & \\
Income (categorical) & 3.22 & 1.58 \\
Education (categorical) & 0.38 & 0.48 \\
Mobilized (binary) & 1.24 & 1.71 \\
Age (quantitative) & 0.02 & 0.13 \\
Gender (binary) & 0.16 & 0.36 \\
Asian & 0.10 & 0.29 \\
Black & 0.01 & 0.08 \\
Hispanic & 0.35 & 0.48 \\
Other & 2.76 & 0.90 \\
Republican & 0.81 & 1.14 \\
Liberal & 0.71 & 0.45 \\
Political interest (scale) & 5.29 & 2.44 \\
Political efficacy (scale) & 3.22 & 1.58 \\
\hline
\end{tabular}

Table 3 displays the Pearson correlation coefficients for the variables described above. The two independent variables are not highly correlated $(r=0.34)$, providing some confidence that they tap into different aspects of civic participation. The correlation matrix also shows that the independent variables are all significantly correlated with the three modes of political participation.

Table 4 presents three models with different modes of political participation as the dependent variables. As the dependent variables for the first two models are all count variables, the explanatory variables are thus the log of expected counts. To facilitate interpretation, incidence rate ratio (IRR) is calculated. IRR represents the estimated ratio for a one-unit increase in the independent variables, holding other variables constant in the model. The value of IRR is either above or below 1. If IRR is above 1, the value from IRR minus 1 indicates the extent to which the dependent variables increase with a one-unit change in the independent variables, and vice versa.

Model 1 examines factors associated with formal mode of participation. On average, holding constant other factors, with one additional increase in the number of affiliations in civic associations, the expected log count of the number of formal political acts increases by $0.058(p<0.05)$, supporting H1. In 
Table 3: Correlation matrix.

\begin{tabular}{|c|c|c|c|c|c|c|c|c|c|c|c|}
\hline & Variables & 1 & 2 & 3 & 4 & 5 & 6 & 7 & 8 & 9 & 10 \\
\hline 1 & $\begin{array}{l}\text { Formal } \\
\text { mode of } \\
\text { participation }\end{array}$ & 1.00 & & & & & & & & & \\
\hline 2 & $\begin{array}{l}\text { Informal } \\
\text { mode of } \\
\text { participation }\end{array}$ & $0.57^{\star}$ & 1.00 & & & & & & & & \\
\hline 3 & Voting & $0.26^{\star}$ & $0.19^{*}$ & 1.00 & & & & & & & \\
\hline 4 & Membership & $0.41^{\star}$ & $0.33^{*}$ & $0.22^{\star}$ & 1.00 & & & & & & \\
\hline 5 & Intensity & $0.29^{\star}$ & $0.33^{*}$ & $0.13^{*}$ & $0.34^{\star}$ & 1.00 & & & & & \\
\hline 6 & Income & $0.17^{\star}$ & $0.13^{*}$ & $0.20^{*}$ & $0.23^{*}$ & $0.13^{\star}$ & 1.00 & & & & \\
\hline 7 & Education & $0.25^{\star}$ & $0.28^{\star}$ & $0.31^{*}$ & $0.36^{\star}$ & $0.28^{\star}$ & $0.39^{\star}$ & 1.00 & & & \\
\hline 8 & Mobilization & $0.33^{\star}$ & $0.29^{\star}$ & $0.16^{*}$ & $0.34^{\star}$ & $0.17^{\star}$ & $0.14^{\star}$ & $0.19^{\star}$ & 1.00 & & \\
\hline 9 & Age & $0.08^{\star}$ & $-0.06^{*}$ & $0.21^{*}$ & $0.12^{\star}$ & $-0.08^{\star}$ & -0.04 & $-0.07^{\star}$ & 0.05 & 1.00 & \\
\hline 10 & Gender & $0.08^{\star}$ & 0.02 & 0.00 & 0.00 & 0.02 & $0.10^{\star}$ & -0.04 & -0.03 & 0.00 & 1.00 \\
\hline 11 & Asian & -0.04 & $-0.01-$ & -0.04 & 0.01 & -0.01 & 0.03 & $0.08^{*}$ & -0.03 & $-0.08^{*}$ & -0.02 \\
\hline 12 & Black & -0.03 & -0.06 & 0.02 & -0.04 & -0.02 & $-0.14^{\star}$ & $-0.07^{*}$ & 0.00 & -0.05 & -0.04 \\
\hline 13 & Hispanic & -0.05 & -0.06 & $-0.20^{*}$ & $-0.11^{\star}$ & 0.00 & $-0.10^{\star}$ & $-0.08^{*}$ & $-0.06^{\star}$ & $-0.20^{*}$ & 0.03 \\
\hline 14 & Other & 0.04 & 0.01 & 0.00 & 0.04 & 0.08 & 0.00 & 0.00 & -0.02 & -0.02 & 0.00 \\
\hline 15 & Republican & 0.00 & -0.03 & $0.15^{*}$ & 0.04 & -0.01 & $0.18^{*}$ & $0.09^{*}$ & 0.00 & 0.00 & 0.02 \\
\hline 16 & Liberal & $0.09^{*}$ & $0.08^{*}$ & 0.02 & 0.03 & 0.04 & $-0.13^{\star}$ & -0.05 & 0.04 & 0.04 & -0.03 \\
\hline 17 & $\begin{array}{l}\text { Political } \\
\text { interest }\end{array}$ & $0.38^{\star}$ & $0.32^{\star}$ & $0.23^{*}$ & $0.26^{*}$ & $0.18^{\star}$ & $0.17^{\star}$ & $0.22^{*}$ & $0.28^{\star}$ & $0.09^{*}$ & $0.12^{*}$ \\
\hline \multirow[t]{2}{*}{18} & $\begin{array}{l}\text { Political } \\
\text { efficacy }\end{array}$ & $0.16^{\star}$ & $0.11^{*}$ & $0.13^{*}$ & $0.16^{*}$ & 0.07 & $0.17^{\star}$ & $0.18^{*}$ & $0.09^{*}$ & -0.01 & -0.05 \\
\hline & Variables & 11 & & 12 & 13 & 14 & & 15 & 16 & 17 & 18 \\
\hline 11 & Asian & 1.00 & & & & & & & & & \\
\hline 12 & Black & -0.06 & 1.00 & & & & & & & & \\
\hline 13 & Hispanic & -0.04 & -0.14 & & 1.00 & & & & & & \\
\hline 14 & Other & -0.01 & -0.04 & & -0.03 & 1.00 & & & & & \\
\hline 15 & Republican & -0.01 & -0.22 & & -0.05 & 0.02 & 1.0 & & & & \\
\hline 16 & Liberal & -0.01 & 0.22 & & 0.03 & 0.00 & -0.7 & $75^{\star}$ & 1.00 & & \\
\hline 17 & $\begin{array}{l}\text { Political } \\
\text { interest }\end{array}$ & 0.01 & -0.06 & & -0.05 & 0.00 & & $09^{*}$ & 0.03 & 1.00 & \\
\hline 18 & $\begin{array}{l}\text { Political } \\
\text { efficacy }\end{array}$ & -0.03 & -0.03 & & $-0.07^{*}$ & 0.03 & & $14^{*}$ & -0.05 & $0.26^{*}$ & 1 \\
\hline
\end{tabular}

other words, for each one-unit increase in the number of civic associations, the expected number of political acts in which one engages increases by a factor of 1.059 , or $5.9 \%$. Regarding the intensity of involvement, adjusting for other factors, for each one-unit increase in the level of involvement in the voluntary organization at which one is most active, the expected number of political acts increases by $14.4 \%(p<0.001)$. H3 is supported. Thus, the intensity of involvement matters more than the scope of memberships in formal participation. 
Table 4: Parameter estimates of factors associated with various modes of political participation.

\begin{tabular}{|c|c|c|c|c|c|c|}
\hline & \multicolumn{2}{|c|}{$\begin{array}{r}\text { Model } 1 \\
\text { Formal participation } \\
\text { (negative binomial) }\end{array}$} & \multicolumn{2}{|c|}{$\begin{array}{r}\text { Model } 2 \\
\text { Informal participation } \\
\text { (negative binomial) }\end{array}$} & \multicolumn{2}{|r|}{$\begin{array}{r}\text { Model } 3 \\
\text { Voting } \\
\text { (logistic) }\end{array}$} \\
\hline & Beta & IRR & Beta & IRR & Beta & Odds-Ratio \\
\hline Memberships & $0.058^{*}$ & 1.059 & 0.013 & 1.013 & 0.055 & 1.056 \\
\hline $\begin{array}{l}\text { Intensity of } \\
\text { involvement }\end{array}$ & $0.134^{\star \star \star}$ & 1.144 & $0.152^{\star \star \star}$ & 1.164 & 0.101 & 1.107 \\
\hline \multicolumn{7}{|l|}{ Control variables } \\
\hline Income & 0.005 & 1.005 & -0.019 & 0.981 & 0.058 & 1.059 \\
\hline Education & 0.043 & 1.044 & $0.075^{*}$ & 1.078 & $0.441^{\star \star \star}$ & 1.555 \\
\hline Mobilization & $0.483^{\star \star \star}$ & 1.621 & $0.295^{\star \star}$ & 1.343 & 0.206 & 1.229 \\
\hline Age & -0.000 & 1.000 & $-0.013^{\star \star \star}$ & 0.987 & $0.043^{\star \star \star}$ & 1.043 \\
\hline Gender $($ male $=1)$ & 0.087 & 1.091 & 0.016 & 1.016 & -0.164 & 0.849 \\
\hline \multicolumn{7}{|c|}{ Race (Whites as reference) } \\
\hline Asian & -0.539 & 0.583 & -0.407 & 0.665 & -1.247 & 0.287 \\
\hline Black & -0.255 & 0.775 & $-0.428^{\star *}$ & 0.652 & 0.149 & 1.160 \\
\hline Hispanic & -0.227 & 0.797 & $-0.650^{\star \star}$ & 0.522 & $-1.006^{\star}$ & 0.344 \\
\hline Other & 0.629 & 1.877 & 0.410 & 1.507 & too few cases & \\
\hline \multicolumn{7}{|c|}{ Party identification (Independent as reference) } \\
\hline Republican & $0.483^{*}$ & 1.621 & -0.117 & 0.889 & $1.343^{\star *}$ & 3.830 \\
\hline Liberal & $0.645^{\star \star}$ & 1.907 & 0.144 & 1.155 & 0.681 & 1.975 \\
\hline Political interest & $0.449^{* * *}$ & 1.566 & $0.281^{\star \star \star}$ & 1.324 & $0.413^{*}$ & 1.512 \\
\hline Political efficacy & 0.046 & 1.047 & -0.026 & 0.975 & -0.042 & 0.958 \\
\hline Constant & $-2.698^{\star \star \star}$ & 0.067 & $-0.623^{*}$ & 0.536 & $-4.345^{\star \star \star}$ & 0.013 \\
\hline $\mathrm{N}$ & 521 & & 520 & & 521 & \\
\hline $\begin{array}{l}\text { Model fit } \\
\quad \text { (Chi-square) }\end{array}$ & 168.26 & & 145.52 & & 106.38 & \\
\hline
\end{tabular}

Note: ${ }^{\star} p<0.05,{ }^{\star \star} p<0.01,{ }^{\star \star \star} p<0.001$.

Among the control variables, neither income nor education is statistically significant. Compared to those who were not asked by their friends or relatives, the expected number of formal political acts for those who were asked to participate is $62.1 \%$ higher $(p<0.001)$. This is consistent with the findings from social network scholars who argue that the recruitment effect is strong among those who have a close relationship. This kind of embeddedness provides quality information on politics, mutual trust, and certainty (McAdam and Paulsen 1993). In addition, holding constant other factors, compared to those who are independent from both parties, the expected number of formal political acts for 
those who consider themselves as more liberal is $90.7 \%$ higher $(p<0.01)$, and this number is $62.1 \%$ higher for Republicans. Those who report being more interested in politics engage more in formal political participation $(56.6 \%, p<0.001)$.

Model 2 examines factors associated with informal political participation. Interestingly, the scope of memberships is not statistically significant anymore, rejecting H2. The intensity of involvement remains significant, and the effect is similar $(16.4 \%, p<0.001)$ to that in formal political action. H4 is thus supported. Income is not statistically significant in predicting one's participation in informal political activities, but education is negatively associated with informal political participation $(p<0.05)$. In other words, people with higher level of education tend to engage in informal participation less. Furthermore, mobilization remains significant. Adjusting for other factors, the expected number of informal political acts for those who were asked to participate is $34.3 \%$ higher than for those who were not asked $(p<0.01)$. Political interest remains significant (beta $=0.281, p<0.001$ ). The effect of age is consistent with what the existing studies find. Controlling for other factors, one additional year of increase in age decreases the expected count of informal political acts by $1.3 \%(p<0.001)$. This makes sense since younger people are usually more likely to participate in demonstrations or illegal protests. Two of the race variables are significant in this model. Holding constant other variables, compared to Whites, the expected numbers of informal political acts for Blacks and Hispanics are significantly lower by $34.8 \%$ and $47.8 \%(p<0.01 ; p<0.01)$, respectively.

Model 3 examines factors associated with voting. Neither the scope nor the intensity of organizational involvement matters. Education has a statistically significant effect on voting. Controlling for other factors, one additional year of education increases one's likelihood of participating in voting by $55.5 \%$ $(p<0.001)$. This effect is substantial, and it implies that more investment in education will probably boost voting rate. Mobilization does not lead to higher voter turnout. Age is statistically significant; one additional year of increase in age increases one's likelihood of voting by $4.3 \%(p<0.001)$, adjusting for other factors. Compared to Whites, Hispanics are statistically less likely to vote (expected ratio $=-65.6 \%, p<0.01)$. Republicans are much more likely $(283 \%)$ to vote than independents, holding constant other factors. Consistent with the negative binomial models, political interests is positively correlated with voting $(p<0.05)$.

To summarize, the results show that memberships only explain one's participation in the formal mode of political activities, and the intensity of involvement, measured by the number of activities one performs at one's most 
active voluntary association, is positively associated with both formal and informal participation models. Neither the scope nor the intensity of organizational involvement explains voting behavior. This finding differs from Wollebæk and Strømsnes (2007) and Alexander et al. (2010), both of which find that the scope of organizational links has substantially strong explanatory power in predicting political participation. Why is this so? Due to the unavailability of data, we are unable to empirically examine this question. We suspect that the difference in findings may be attributed to the distinct characteristics of various modes of political participation. In particular, voting is more individualized participation with minimal policy influence; thus civic associations are not directly associated with voter turnout. Informal political activities are more difficult to carry out and require more commitment. Active involvement in civic associations helps foster political efficacy and "persuade" one to act; simple affiliation may be unable to achieve this. Thus, membership is not related to informal participation.

In addition, the socioeconomic status has more explanatory power in individualized political activities, such as voting. While income is not significant in all three models, education is highly significant in predicting voting and informal participation. Mobilization is positively associated with one's participation in both formal and informal political activities, both of which require more time, efforts, and resources to carry out. The requests from friends or relatives provide an external stimulus to participation.

To further explore the effects of the intensity of involvement, we graphed the expected number of political activities by intensity of involvement in civic associations, adjusting for other factors, see Figure 1. The X-axis indicates the number of activities one performs in the organization, and the Y-axis is the

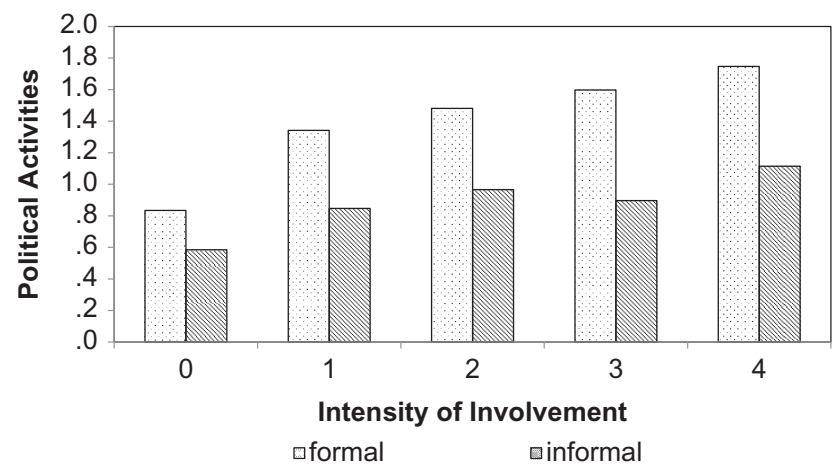

Figure 1: Predicted number of political activities by intensity of involvement in civic associations, adjusting for other factors. 
predicted number of political activities. The two different patterns in the columns indicate two different modes of political participation. We can see that as one is more involved in civic associations, the number of political activities increases across the two modes. But roughly, the increase is more substantial in formal participation mode, suggesting that the effect of the intensity of involvement is larger.

\section{Discussion and Conclusion}

Existing literature depicts the relationship between civic associations and democracy from two perspectives (Torpe 2003). The first highlights the internal democratic role of associations. Through participating in the internal life of associations, one learns democratic norms and values, develops democratic competences, and becomes more active in politics. The second focuses on the external democratic role of associations, which are considered as intermediary institutions between citizens and government. This paper joins the first perspective by examining how civic associations contribute to political participation. Using the Citizenship, Involvement, and Democracy dataset, we showed that participation in politics rises with participation in voluntary associations, even when these associations are quite apolitical. Specifically, we disaggregated political participation into three modes: formal, informal participation, and voting. We then highlighted two aspects of involvement in civic associations: the scope versus the intensity. The former argues that civic associations serve as networks of bridging social ties through which novel information travel. The more affiliations to which one belongs, the more exposed one is to social influence, and thus, the more political activities one will participate in. In contrast, the latter proposes that civic associations are socialization agents through which the seeds for generalized social trust, identification, and cohesion sprout. The more involved one is in the active associations, the more political activities one will engage in. We found that the intensity argument is supported in two types of political activities, including formal and informal participation. However, the number of affiliations affects formal participation but does not have a significant impact on informal participation. This is interesting because it enriched our understanding on the longstanding debate between bonding and bridging social capital (Burt 2000). Bonding ties are the strong ties that exist within closed networks. They help disseminate information among densely connected members within a certain group, reducing the cost of obtaining information. They also help build and reinforce participants' identities and cultivate collective norms. Knoke (1990), for example, examines the 
networks of political action, arguing that when people discuss political matters with their intimates very frequently, their interests and participation in national campaigns and voting will be enhanced. In contrast, bridging ties are the weak ties that exist between groups, creating "brokerage opportunities" and providing non-redundant information (Burt 2000; Granovetter 1973). Our study found that the intensity of organizational involvement matters more than the scope. Thus, bonding social capital is more important in promoting political actions.

Furthermore, we found that the classic socioeconomic status model works better in predicting individualized political activities, such as voting, whereas mobilization has strong explanatory power in predicting both formal and informal political acts-those require more efforts and are more difficult to carry out.

This study contributes to the literature on political participation in three ways. First, by identifying, conceptualizing, and unpacking political participation, it attempts to bring some conceptual order to a research area that has been extensively explored in recent decades. Second, by incorporating these dimensions in multivariate models, it disentangles the explanatory power of the often discussed mechanisms in each type of political participation. Finally, by giving special attention to organizational involvement and the mobilization effects, the research highlights that compared to socioeconomic characteristics, associational life, especially one's depth of involvement in civic associations and social network, have a more significant effect in political recruitment.

Our study carries important implications for policy makers and nonprofit practitioners. Over the past two decades, the nonprofit sector has become increasingly professionalized. Many small, local-based civic associations have been replaced by large, membership-based associations in which members do not have frequent interaction with each other and the organizations. The intense face-to-face encounters and the benefits that these interactions generate seem to have withered. However, it is these interactions that cultivate political interest, efficacy, and participatory norms. Facilitating frequent interactions thus seems critical. While the growth of nationwide, professionalized associations seems to be an inevitable trend, establishing an institutional framework in which robust local chapters are supported is a viable strategy. In particular, guidelines on how to develop leadership, integrate resources, and engage members should be provided to these local chapters. For nonprofit managers, more attention should be paid to encourage citizens to involve actively in associational activities, such as attending meetings, holding discussion sessions, or organizing activities. In order to nurture the nonprofit sector, policy makers should focus their funds and energies on building the capacity of local-based civic associations.

This study has limitations as well. The study only looks at one way of a probably two-way relationship between voluntary and political participation. 
Clearly, the two variables are interconnected and endogenous. That is, involvement in voluntary organizations helps foster civic skills and democratic values and thus can promote political participation, but in turn, political participation may reinforce one's level of engagement in voluntary associations. As Diani (2004) asserts, the process of movement participation is dynamic and diachronic in the sense that memberships in voluntary organizations contribute to social movement mobilization and this very participation also helps forge new bonds among participants. Longitudinal data are required in order to address the endogeneity problem. Nonetheless, we are cautious in establishing the link between civic associations and political participation. When discussing the role of civic associations, we confined our purview to involvements in organizations that do not take stands on public issues. This permits us to make the assumption of causal priority for civic organizations. In addition, the dataset used in this study was collected in 2006. Now that almost 10 years have passed, it is possible that the participation landscape has changed greatly, and the impact of the factors on political participation reported here may vary. Future study should use a more up-to-date data set and examine how the mechanisms shape various modes of political participation.

\section{References}

Alexander, D. T., J. Barraket, J. M. Lewis, and M. Considine. 2010. "Civic Engagement and Associationalism: The Impact of Group Membership Scope Versus Intensity of Participation." European Sociological Review jcq047. 28 (1):43-58.

Almond, G., and S. Verba. 1963. The Civic Culture: Political Attitudes and Democracy in Five Countries. Princeton: Princeton University.

Andrews, K. T., M. Ganz, M. Baggetta, H. Han, and C. Lim. 2010. "Leadership, Membership, and Voice: Civic Associations That Work1.” American Journal of Sociology 115 (4):1191-242.

Berry, J. M., K. E. Portney, and K. Thomson. 1993. The Rebirth of Urban Democracy. Washington, D.C.: Brookings Institution Press.

Booth, J. A., and P. B. Richard. 1998. "Civil Society, Political Capital, and Democratization in Central America." The Journal of Politics 60 (03):780-800.

Brady, H. E., K. L. Schlozman, and S. Verba. 1999. "Prospecting for Participants: Rational Expectations and the Recruitment of Political Activists." American Political Science Review 93 (1):153-68.

Brady, H. E., S. Verba, and K. L. Schlozman. 1995. "Beyond SES: A Resource Model of Political Participation." American Political Science Review 89 (2):271-94.

Bratton, M. 1999. "Political Participation in a New Democracy Institutional Considerations From Zambia." Comparative Political Studies 32 (5):549-88.

Burt, R. S. 2000. "The Network Structure of Social Capital." Research in Organizational Behavior 22:345-423. 
Cameron, A. C., and P. K. Trivedi. 2013. Regression Analysis of Count Data, Vol. 53. New York, NY, USA: Cambridge University Press.

Dalton, R. J. 2008. "Citizenship Norms and the Expansion of Political Participation." Political Studies 56 (1):76-98.

Tocqueville, Alexis de, Henry Reeve, and Bruce Frohnen. 2002. Washington, DC: Democracy in America. n.p.

Diani, M. 2004. Networks and Participation. Malden, MA: Blackwell Publishing.

Diani, M., and D. McAdam. 2003. Social Movements and Networks: Relational Approaches to Collective Action. Oxford: Oxford University Press.

Downs, A. 1957. "An Economic Theory of Political Action in a Democracy." The Journal of Political Economy 65 (2):135-50.

Eliasoph, N. 1998. Avoiding Politics: How Americans Produce Apathy in Everyday Life. Cambridge, U.K.; New York, NY, USA: Cambridge University Press.

Erickson, B. H., and T. A. Nosanchuk. 1990. "How an Apolitical Association Politicizes." Canadian Review of Sociology/Revue Canadienne De Sociologie 27 (2):206-19.

Fernandez, R. M., and D. McAdam. 1988. "Social Networks and Social Movements: Multiorganizational Fields and Recruitment to Mississippi Freedom Summer." Paper presented at the Sociological Forum.

Fung, A. 2003. "Associations and Democracy: Between Theories, Hopes, and Realities." Annual Review of Sociology 29:515-39.

Granovetter, M. S. 1973. "The Strength of Weak Ties." American Journal of Sociology 78 (6):1360-80.

Hooghe, M. 2003. "Participation in Voluntary Associations and Value Indicators: The Effect of Current and Previous Participation Experiences." Nonprofit and Voluntary Sector Quarterly 32 (1):47-69.

Howard, M. M., J. L. Gibson, and D. Stolle. 2006. United States Citizenship, Involvement, Democracy (CID) Survey. ICPSR04607-v1. Ann Arbor, MI: Inter-university Consortium for Political and Social Research [distributor], 2007-11-14. http://doi.org/10.3886/ ICPSR04607.v1

Huckfeldt, R., and J. Sprague. 1992. "Political Parties and Electoral Mobilization: Political Structure, Social Structure, and the Party Canvass." American Political Science Review 86 (1):70-86.

Jeong, H. 0. 2013. "From Civic Participation to Political Participation.” Voluntas: International Journal of Voluntary and Nonprofit Organizations 24 (4):1138-58. doi:10.1007/s11266-0129316-7.

Kam, C. D., and C. L. Palmer. 2008. "Reconsidering the Effects of Education on Political Participation." The Journal of Politics 70 (3):612-31.

Kenny, C. B. 1992. "Political Participation and Effects From the Social Environment." American Journal of Political Science 36 (1):259-67.

Kitts, J. A. 2000. "Mobilizing in Black Boxes: Social Networks and Participation in Social Movement Organizations." Mobilization: An International Quarterly 5 (2): 241-57.

Klandermans, B. 2003. “Collective Political Action." Oxford Handbook of Political Psychology, edited by Sears, David 0., Huddy, Leonie, Jervis, Robert, 670-709. New York, NY, US: Oxford University Press. 2003. x, 822 pp.

Knoke, D. 1990. "Networks of Political Action: Toward Theory Construction." Social Forces 68 (4):1041-63. 
Leighley, J. 1996. "Group Membership and the Mobilization of Political Participation." The Journal of Politics 58 (02):447-63.

Lim, C. 2008. "Social Networks and Political Participation: How Do Networks Matter?" Social Forces 87 (2):961-82.

Long, J. S., and J. Freese. 2006. Regression Models for Categorical Dependent Variables Using Stata. 3rd ed. College Station, TX: Stata Press.

McAdam, D. 2010. Political Process and the Development of Black Insurgency, 1930-1970. Chicago: University of Chicago Press.

McAdam, D., and R. Paulsen. 1993. "Specifying the Relationship Between Social Ties and Activism." American Journal of Sociology 99 (3):640-67.

McClurg, S. D. 2003. "Social Networks and Political Participation: The Role of Social Interaction in Explaining Political Participation." Political Research Quarterly 56 (4):449-64.

Milbrath, L. W. 1965. Political Participation: How and Why Do People Get Involved in Politics? Chicago: Rand McNally.

Milbrath, L. W. 1981. "Political Participation." In The Handbook of Political Behavior, edited by Samuel L. Long 197-240. New York: Plenum Press.

Mutz, D. C. 2002. "The Consequences of Cross-Cutting Networks for Political Participation." American Journal of Political Science 46 (4):838-55.

Newman, B. J., and B. L. Bartels. 2010. "Politics at the Checkout Line: Explaining Political Consumerism in the United States.” Political Research Quarterly 64 (4):803-17.

Norris, P. 2002. Democratic Phoenix: Reinventing Political Activism. Cambridge: Cambridge University Press.

Olson, M. 1965. The Logic of Collective Action: Public Goods and the Theory of Groups. Cambridge: Harvard University Press.

Paik, A., and L. Navarre-Jackson. 2010. "Social Networks, Recruitment, and Volunteering: Are Social Capital Effects Conditional on Recruitment?" Nonprofit and Voluntary Sector Quarterly 40 (3):476-96.

Park, C. -U, and S. V. Subramanian. 2012. "Voluntary Association Membership and Social Cleavages: A Micro-Macro Link in Generalized Trust.” Social Forces 90 (4):1183-205.

Pattie, C., P. Seyd, and P. Whiteley. 2003. "Citizenship and Civic Engagement: Attitudes and Behaviour in Britain." Political Studies 51 (3):443-68.

Paxton, P. 2002. "Social Capital and Democracy: An Interdependent Relationship." American Sociological Review 67 (2):254-77.

Paxton, P. 2007. “Association Memberships and Generalized Trust: A Multilevel Model Across 31 Countries." Social Forces 86 (1):47-76.

Pollock, P. H. 1982. "Organizations as Agents of Mobilization: How Does Group Activity Affect Political Participation?” American Journal of Political Science 26 (3):485-503.

Putnam, R. D. 2000. Bowling Alone: The Collapse and Revival of American Community. New York: Simon and Schuster.

Quintelier, E. 2008. “Who Is Politically Active: The Athlete, the Scout Member or the Environmental Activist? Young People, Voluntary Engagement and Political Participation.” Acta Sociologica 51 (4):355-70.

Quintelier, E. 2012. "Socialization or Self-Selection? Membership in Deliberative Associations and Political Attitudes." Nonprofit and Voluntary Sector Quarterly 42 (1):174-92.

Salamon, L. M., and H. K. Anheier. 1992. "In Search of the Non-Profit Sector. I: The Question of Definitions." Voluntas: International Journal of Voluntary and Nonprofit Organizations 3 (2):125-51. 
Schachter, H. L. 2011. "Reflections on Political Engagement and Voluntary Association Governance.” Nonprofit and Voluntary Sector Quarterly 40 (4):703-19.

Skocpol, T., M. Ganz, and Z. Munson. 2000. "A Nation of Organizers: The Institutional Origins of Civic Voluntarism in the United States." American Political Science Review 94 (3):527-46.

Sobieraj, S., and D. White. 2004. “Taxing Political Life.” The Sociological Quarterly 45 (4):739-64.

Somma, N. M. 2010. "How Do Voluntary Organizations Foster Protest? the Role of Organizational Involvement on Individual Protest Participation.” The Sociological Quarterly 51 (3):384-407.

Stolle, D., M. Hooghe, and M. Micheletti. 2005. "Politics in the Supermarket: Political Consumerism as a Form of Political Participation." International Political Science Review 26 (3):245-69.

Torpe, L. 2003. "Democracy and Associations in Denmark: Changing Relationships Between Individuals and Associations?" Nonprofit and Voluntary Sector Quarterly 32 (3):329-43.

Verba, S., and N. H. Nie. 1972. Participation in America. New York: Harper \& Row.

Verba, S., K. L. Schlozman, and H. E. Brady. 1995. Voice and Equality: Civic Voluntarism in American Politics. Cambridge, Mass: Harvard University Press.

Verba, S., K. L. Schlozman, H. E. Brady, and N. Nie. 1990. American Citizen Participation Study. ICPSR06635-v1. Ann Arbor, MI: Inter-university Consortium for Political and Social Research [distributor], 1995. http://doi.org/10.3886/ICPSR06635.v1

Verba, S., K. L. Schlozman, H. Brady, and N. H. Nie. 1993. "Citizen Activity: Who Participates? What Do They Say?” American Political Science Review 87 (2):303-18.

Walker, E. T. 2008. Contingent pathways from joiner to activist: The indirect effect of participation in voluntary associations on civic engagement. Paper presented the Sociological Forum.

Wollebaek, D., and P. Selle. 2002. "Does Participation in Voluntary Associations Contribute to Social Capital? the Impact of Intensity, Scope, and Type." Nonprofit and Voluntary Sector Quarterly. 31 (1):32-61.

Wollebæk, D., and K. Strømsnes. 2007. "Voluntary Associations, Trust, and Civic Engagement: A Multilevel Approach.” Nonprofit and Voluntary Sector Quarterly 37 (2):249-63.

Wuthnow, R. 2002. “United States: Bridging the Privileged and Marginalized?" In Democracies in Flux: The Evolution of Social Capital in Contemporary Society, R. D. Putnam (Ed, pp.103-136). Oxford: Oxford University Press.

Zukin, C., S. Keeter, M. Andolina, K. Jenkins, and M. X. D. Carpini. 2006. A New Engagement? Political Participation, Civic Life, and the Changing American Citizen. New York: Oxford University Press. 